\title{
Elites estatais e reforma do estado na nova repú- blica: o projeto ENAP e a formação da carreira de gestor governamental no Brasil
}

\author{
André Teles Guedes \\ Orientador: Carlos Benedito de Campos Martins \\ Tese de Doutorado \\ Data da defesa: 18.01.2013
}

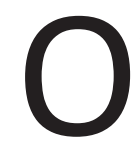

s objetos desta pesquisa são: 1) a atuação das elites burocráticas do Poder Executivo Federal no processo de transição política no Brasil, nos anos 1980; 2) as frentes de reforma na Nova República, nas áreas social, econômica e administrativa e 3) as tentativas de renovação da gestão pública representadas pela criação da Escola Nacional de Administração Pública (ENAP) e da Carreira de Gestor Governamental (EPPGG). Esse era um contexto de reinstitucionalização da função diretiva do Estado e de deslocamento das fronteiras entre o burocrático e o político no setor público brasileiro. A hipótese central aqui defendida é de que a ENAP e a Carreira de Gestor Governamental eram duas opções inovadoras em frente ao dilema sobre quais seriam os papéis cabíveis a políticos e administradores na nova ordem democrática, mas também eram opções sem enraizamento nos pactos e agendas de prioridades que viabilizaram a mudança de regime no País. A Escola e a Carreira estavam em dissonância com as principais tendências de recomposição das elites estatais na transição a partir do regime militar e sofreram bloqueios em razão disso, mas a pesquisa procurou desconstruir algumas narrativas sobre esses conflitos interburocráticos, que associam as resistências impostas à ENAP e à Carreira pelos grupos de funcionários da Fazenda e Planejamento a interesses meramente corporativistas. Com um trajeto pelos estudos sobre as burocracias dos regimes militares e sobre as transições no Brasil e na América Latina, buscou-se aqui uma melhor identificação dos grupos integrantes das "tecnoburocracias" e de suas contribuições para a modernização administrativa e econômica do País, na segunda metade do século XX. Buscou-se revelar algumas confluências entre as ideias de tecnocratização e profissionalização das altas funções públicas e seus elos com as aspirações pela reconstrução do Estado sob bases mais democráticas, mostrando que, nos anos 1980, as propostas da SEDAP não eram os únicos projetos de modernização em curso, tampouco os grupos que a elas puseram-se representavam interesses univocamente antidemocráticos.

Palavras-chave: Tecnoburocracia, Transição, Democracia, ENAP, Gestores Governamentais. 